\title{
Aflatoxins in bird feed collected from various areas of Lahore city
}

\author{
Alim-un-Nisa*, S. H. Abidi, Qurat-ul-Ain Syed, A. Saeed, S. Masood, S. Hina and Hamood-ur-Rehman \\ Food and Biotechnology Research Centre, PCSIR Labs Complex, Ferozpur Road, Lahore, Pakistan
}

\begin{abstract}
The objective of this study was to estimate total aflatoxin in bird feed. Total 50 birds feed samples were collected from different markets and birds shops in Lahore. Total aflatoxin B1, B2, G1, and G2 were estimated using the Thin Layer Chromatography (TLC) method. The daily intake of aflatoxin in bird's feed is a 300ppb threshold by FDA. Total 50 samples were examined, among them $22 \%$ were contaminated with aflatoxin B1 and B2 and the rest of $40 \%$ samples were contaminated only with aflatoxin B1. Aflatoxin G1 and G2 were not detected in any feed. The results showed that $42 \%$

Received: 18 August 2021

Revised: 19 September 2021

Accepted: 19 October 2021 of samples were contaminated within the permissible limit, $20 \%$ were unfit due to having above the allowable limit, and 38\% were fit, which did not show any aflatoxin. The current study has demonstrated the easy way of providing the determination of aflatoxin in bird's feed.
\end{abstract}

DOI: https://doi.org/10.3329/bjsir.v56i4.57198
Keywords: Aflatoxin; Birds feed; Permissible level; Poultry

\section{Introduction}

The discovery and separation of aflatoxin are well known to be an aftereffect of examinations on the puzzling Turkey-X disease in 1960, which brought about the loss of a few thousand turkey poults in the United Kingdom. The reason for significant mortality in turkey poults and similar outbreaks in other farm animals could be connected with the utilization of rotten Brazilian shelled nut meals in the diet of affected animals (Yunus et al., 2011). The name aflatoxin using the first letter from Aspergillus and the initial three letters from flavus were proposed in 1962 (Patterson, 1977). Aflatoxin was around the same time, detached in crystalline shape in the Netherlands (Vander et $a l ., 1962$ ) and isolated into two segments, B and G, in the United Kingdom (Nesbet et al., 1962).

One of the major groups of mycotoxins that cause aflatoxicosis in living creatures is aflatoxin (Aquino and Corrêa, 2011). Aflatoxin, presumably the most considered and primarily known mycotoxins, was initially noted in the early 1960s. They are among the most potent mutagenic substances known; there is extensive trial and epidemiological confirmation that they initiate liver cancer (Boutrif, 1998). The significant aflatoxins (afs) comprise aflatoxins $\mathrm{B}_{1}, \mathrm{~B}_{2}, \mathrm{G}_{1}$ and $\mathrm{G}_{2}$ created by certain toxigenic strains of $A$. flavus, A. parasiticus, and A. nominus. Aflatoxin $M_{1}$ (AFM1), a hydroxylated metabolite, found essentially in animal tissues and liquids (milk and urine) is a metabolic result of aflatoxin $\mathrm{B}_{1}$ (AFB1), and these mycotoxins are not found in feed grains. The term aflatoxins allude to a class of substance mixes of related structures; among them, aflatoxin $\mathrm{B}_{1}$ is considered the most potent cancer-causing agent (Boutrif, 1998). Aflatoxins can affect various animals, including fishes, rodents, waterfowl, poultry, swine, and dairy cattle (Kumar et al., 2017). Aflatoxins can be available in the milk of dairy cows, the meat of swine, or chicken eggs if the creatures devour adequate quantity in their feed (Aquino and Corrêa, 2011).

A wide variety of nuts, cereals, and grains are available for birds in the food market. Mycotoxins probably contaminate these feed ingredients under some circumstances. Among all mycotoxins the most important aflatoxin has been detected in wild bird's food (Scudamore et al., 1997). 
On the International Union for Conservation of Nature (IUCN) Red List, the red-crowned Crane has been classified as an endangered and rarest species. The current population is evaluated to be 2750 individuals. In late October, a large proportion of the people migrated from China to Yenchang. In early March, it overwinters in Yenchang Biosphere Reserve, China's largest wintering area (Ma and Tang, 1999; Wang, 2008).

Diets for Red-crowned Crane are rice, grains, wheat seedlings, shrimps, crabs, shellfishes, fishes, seepweed seeds, and leaves. However, they can eat both plants and animal origin, so they are called omnivorous (Dong et al., 2005). Some foods are contaminated with mycotoxins, especially aflatoxin, due to the climatic zone in which Yenchang is located with temperature and moistness suitable for mold growth and aflatoxin production (Fan, 2008). Such conditions may have a harsh effect on the fitness and reproduction of these cranes and thus probably threatens to population (Liu et al., 2016).

Aflatoxin also impacts wildlife populations, and the significance of the problem for wildlife is mainly unknown (Higgins et al., 1992). In the field of nature, data concerning the impacts of aflatoxins are limited. Exposure of agricultural grains to moisture and other environmental conditions present in the fields can lead to significant production of AF. However, in 1977-1978 wintering season, extensive waterfowl died off in the two separate areas of Texas; approximately 7000 ducks and 500 geese scumbled to aflatoxicosis after consuming contaminated grain. Because of supplemental feeding, northern bobwhite may also encounter AF contaminated grain (Hernández and Guthery, 2012). Most feeders have open feeder ports that permit coordinated access of dampness to grain within the feeder. Aspergillus requires humidity between 70 and $90 \%$ and temperature between 6 and $46^{\circ} \mathrm{C}$. If the moisture content of the substrate is between 12 and 17\%, Aspergillus spp. can grow with this lower relative humidity. In the rolling planes of Texas and Oklahoma, these environmental conditions may occur throughout the year. Though fungal growth on grain in feeders is often readily apparent, feeders are rarely cleaned, and new feeds are often added to that already presents in feeders. This practice may promote the production of AF in feeders and cause aflatoxin in northern bobwhite (Smith and Moss, 1985).
In poultry and livestock, the cause of liver damage is mostly occurring by aflatoxin, the most frequently known mycotoxins. They lower the profitability of poultry production by reduced growth, feed conversion efficiency, egg production, and break in immunity leading to heavy financial losses. Many investigators did a survey of mycotoxins in different feedstuffs of plant origin done worldwide (Ueno, 1977; Siame and Lovelace, 1989). Poultry feed, namely starter, grower, developer layer, and branare found to be most common. During pre-harvest and post-harvest, fungal attack and aflatoxin production may occur, which are encouraged by environmental factors like temperature and humidity (Khan et al., 2005).

During crop production and storage, cereals and plant proteins used in poultry feeds have been associated with contaminants produced by molds that can deteriorate food and feeds and adversely affect living creatures (Khan et al., 2005).

In poultry mesenteric venous blood, the Aflatoxin B1 gets absorbed immediately by the small intestine (Hsieh and Wong, 1994). To prevent aflatoxin buildup in poultry feeds, regular monitoring of AFB1 in poultry feed is essential (Rosa et al., 2006).

\section{Materials and methods}

\section{Sample collection}

Bird feed samples were collected from different bird shops of Lahore. Among them, 10 samples each were collected from Samanabad, Allama Iqbal town, Itehad colony, 10 from Shadman, and Bagh Gul Begum as shown in the map of Lahore city. Samples were prepared for Aflatoxin determination by the Begum's method (Begum et al., 1985). Aflatoxins were detected by Romer's method. Estimation of Aflatoxins in extracts was made by comparison with standard technique (AOAC, 2005).

\section{Chemical and reagents}

Distilled water $(25 \mathrm{ml})$, Diatomaceous earth (25g) (JJS Minerals Co., Ltd., UK), Chloroform (150 ml) (Fine Chemicals and Scientific Co., India), Diethyl Ether (Nandkrishna Chemicals Private Limited, India), Acetone (Kodak Solvent Recovery, Rochester, NY), Chloroform (Pharma Traders Pvt., Ltd., India), Benzene (Buneesha Chemicals Pvt., Ltd., India), Acetonitrile (Hudson Chemicals, Staten Island, NY). 




Fig. 1. Location map for the study area showing the highlighted areas from where samples have been collected

\section{Glassware and machinery}

Conical flask 250ml (Conical Tool Co., Grand Rapids, MI), Grinding mill (GlenMills, Inc., Clifton, New Jersey, USA), Wrist action shaker (ACMAS Technologies Pvt., Ltd., India), Digital Balance (Nan Jung Electronic Co., Ltd., Taiwan), Beaker (Paul Marienfeld, Germany), Filter paper (Whatman Article No.4, US), Hot plate (Eie Instruments Pvt., Ltd., Ahmedabad), TLC Tank (CAMAG Chemieerzeugnisse and Adsorptionstechnik AG, Switzerland), UV cabinet with dual-wavelength 365 and 254nm (Metro Electronic Lab, New Delhi), TLC silica gel 60 F254 plates $20 \times 20 \mathrm{~cm}$ (Union Drug \& Chemical Company, Mumbai), Volumetric flask 100ml (Garg Process Glass India Pvt. Ltd. Malad West, Hyderabad), Micro syringe $25 \mu \mathrm{L}$ (Mana Life Care Private Limited, Noida).

\section{Determination of aflatoxin}

To obtain finely crushed feed, the samples were passed through a grinding mill. Fifty (50) gram of ground sample was added into a conical flask, and the sample number was marked. $25 \mathrm{ml}$ of water and $25 \mathrm{~g}$ Diatomaceous earth, and $150 \mathrm{ml}$ chloroform were added. The flask was shaken on a wrist action shaker set at medium speed for 30 minutes. Samples were filtered in a small beaker through a fluted $12.5 \mathrm{~cm}$ Whatman No.4. Filtrate filled beaker was placed on hot plate. The aflatoxin sample extract was spotted side by side with the aliquots of standard aflatoxin B1, B2, G1, and G2 on percolated TLC silica plate, employing a microsyringe

\section{Results and discussion}

Fifty samples were analyzed for the estimation of aflatoxin. It was observed that $62 \%$ of the examined samples were contaminated with aflatoxin by TLC method. Among them, $22 \%$ were infected with aflatoxin B1 and B2 and the rest of $40 \%$ samples were contaminated only with aflatoxin B1. Aflatoxin G1 and G2 were not detected in any feed. The permissible level of U.S. Food and drug administration of 
Table I. Results of total aflatoxins $B_{1}, B_{2}, G_{1}, G_{2}$ in bird's feed

\begin{tabular}{|c|c|c|c|c|c|c|}
\hline \multirow[t]{2}{*}{$\begin{array}{l}\text { Sr. } \\
\text { No } \\
\end{array}$} & \multirow[t]{2}{*}{ Samples } & \multicolumn{4}{|c|}{ Aflatoxin } & \multirow{2}{*}{$\begin{array}{l}\text { Total } \\
\text { Aflatoxin } \\
B_{1}+B_{2}+G_{1}+G_{2}\end{array}$} \\
\hline & & B1 & B2 & G1 & $\mathrm{G} 2$ & \\
\hline 1 & S 1 & 98.917 & -- & ND & ND & 98.917 \\
\hline 2 & S 2 & 118.7 & -- & ND & ND & 118.7 \\
\hline 3 & S 3 & 385.77 & -- & ND & ND & 385.77 \\
\hline 4 & S 4 & 93.67 & 23.32 & ND & ND & 116.99 \\
\hline 5 & S 5 & -- & -- & ND & ND & -- \\
\hline 6 & S 6 & 96.54 & -- & ND & ND & 96.54 \\
\hline 7 & S 7 & -- & -- & ND & ND & -- \\
\hline 8 & S 8 & 96.97 & -- & ND & ND & 96.97 \\
\hline 9 & S 9 & 102.8 & -- & ND & ND & 102.8 \\
\hline 10 & S 10 & 96.03 & -- & ND & ND & 96.03 \\
\hline 11 & S 11 & -- & -- & ND & ND & -- \\
\hline 12 & S 12 & -- & -- & ND & ND & -- \\
\hline 13 & S 13 & -- & -- & ND & ND & -- \\
\hline 14 & S 14 & 97.45 & -- & ND & ND & 97.45 \\
\hline 15 & S 15 & 93.32 & -- & ND & ND & 93.32 \\
\hline 16 & S 16 & 91.7 & -- & ND & ND & 91.7 \\
\hline 17 & S 17 & -- & -- & ND & ND & -- \\
\hline 18 & S 18 & 79.13 & & ND & ND & 79.13 \\
\hline 19 & S 19 & 92.71 & 23.06 & ND & ND & 115.77 \\
\hline 20 & S 20 & 101.976 & 25.36 & ND & ND & 127.336 \\
\hline 21 & S 21 & 356.10 & -- & ND & ND & 356.10 \\
\hline 22 & S 22 & -- & -- & ND & ND & -- \\
\hline 23 & S 23 & 96.50 & 24 & ND & ND & 120.5 \\
\hline 24 & S 24 & -- & -- & ND & ND & -- \\
\hline 25 & S 25 & 103.47 & 25.7 & ND & ND & 129.17 \\
\hline 26 & S 26 & 365.99 & -- & ND & ND & 365.99 \\
\hline 27 & S 27 & -- & -- & ND & ND & -- \\
\hline 28 & S 28 & 105.2 & 26.17 & ND & ND & 131.37 \\
\hline 29 & S 29 & 103.0 & 25.64 & ND & ND & 128.64 \\
\hline 30 & S 30 & -- & -- & ND & ND & -- \\
\hline 31 & S 31 & 336.31 & -- & ND & ND & 336.31 \\
\hline 32 & S 32 & 346.21 & -- & ND & ND & 346.21 \\
\hline 33 & S 33 & -- & -- & ND & ND & -- \\
\hline 34 & S 34 & 326.42 & -- & ND & ND & 326.42 \\
\hline 35 & S 35 & -- & -- & ND & ND & -- \\
\hline 36 & S 36 & 136.5 & 33.95 & ND & ND & 170.45 \\
\hline 37 & S 37 & 108.80 & 27.06 & ND & ND & 135.86 \\
\hline 38 & S 38 & 375.88 & -- & ND & ND & 375.88 \\
\hline 39 & S 39 & -- & -- & ND & ND & -- \\
\hline 40 & S 40 & -- & -- & ND & ND & -- \\
\hline 41 & S 41 & 316.53 & -- & ND & ND & 316.53 \\
\hline 42 & S 42 & -- & -- & ND & ND & -- \\
\hline 43 & S 43 & -- & -- & ND & ND & -- \\
\hline 44 & S 44 & 306.6 & -- & ND & ND & 306.6 \\
\hline 45 & S 45 & -- & -- & ND & ND & -- \\
\hline 46 & S 46 & 109.7 & 27.3 & ND & ND & 109.7 \\
\hline 47 & S 47 & -- & -- & ND & ND & -- \\
\hline 48 & S 48 & -- & -- & ND & ND & -- \\
\hline 49 & S 49 & 395.66 & -- & ND & ND & 395.66 \\
\hline 50 & S 50 & 150.35 & 37.40 & ND & ND & 187.75 \\
\hline
\end{tabular}


aflatoxin in bird's feed is $300 \mathrm{ppb}$ (Grace et al., 2015). If the amount of aflatoxin exceeds this level, it may cause toxigenic effects on birds and be considered unfit samples. If the amount of aflatoxin in feed samples is within the permissible limit, these samples are considered contaminated but have fewer toxigenic effects. The results showed that $42 \%$ were contaminated within the allowable limit, $20 \%$ samples were unfit, which were above the permissible range, and $38 \%$ samples were fit that didn't show any aflatoxin.

\section{Conclusion}

The present study concluded that the levels of aflatoxins in the given feed samples were $62 \%$. Among them, $22 \%$ were contaminated with aflatoxin B1 and B2 and the rest of $40 \%$ samples were contaminated only with aflatoxin B1. Aflatoxin G1 and G2 were not detected in any feed. The permissible level of U.S. Food and drug administration of aflatoxin in birds' feed is $300 \mathrm{ppb}$. The present study is concluded that this level of aflatoxins mostly above the permissible limit. Thus, the consumption of average amounts of these feeds poses a health risk for the consumer.

\section{References}

AOAC 2005. Official Methods of Analysis, Association of Official Analytical Chemists, Washington DC, USA.

Aquino S and Corrêa B (2011), Aflatoxins in pet foods: a risk to special consumers, INTECH Open Access Publisher.

Begum N, Adil R and Shah FH (1985), Contamination of groundnuts with aflatoxins, Pakistan Journal of Medical Research 24: 129-131.

Boutrif E (1998), Prevent of aflatoxins in Pistachios, Food, Nutrition and Agriculture 21: 32-37.

Dong K, Lv SC and Healy T (2005), Carrying capacity for Red crowned Cranes in the National Yenchang rare bird's nature reserve, Jiangsu Province, China, Acta Ecologica Sinica 25(10): 2608-2615.

Fan Y (2008), Toxic effect of aflatoxin B1, deoxynivalenol tocyprinus carpio and cultured hepatocytes in vitro. $P h D$ Thesis, Nanjing Agriculture University, Nanjing, China.
Grace D, Lindahl JF, Atherstone C, Kangethe EK, Nelson F, Wesonga T and Manyong VM (2015), Aflatoxin standards for feed.

Hernández F and Guthery FS (2012), Beef, brush, and bobwhites: quail management in cattle country, Golden Banner Press, Inc., Corpus Christi, Texas, 182.

Higgins KF, Barta RM, Neiger RD, Rottinghaus GE and Sterry RI (1992), Mycotoxin occurrence in waste field corn and ingesta of wild geese in the northern Great Plains, Prairie Naturalist 24: 31-37.

Hsieh DP and Wong JJ (1994), Pharmacokinetics and excretion of aflatoxins In: The Toxicology of Aflatoxins. Human Health, Veterinary and Agricultural Significance, pp 73-88.

Khan MMH, Chowdhury B, Bhuiya MR and Rahim M (2005), Variation of aflatoxin level in different poultry feeds used in different poultry farms of Bangladesh round the year, International Journal of Poultry Science 4: 382-387.

Kumar P, Mahato DK, Kamle M, Mohanta TK and Kang SG (2017), Aflatoxins: A global concern for food safety, human health and their management, Frontiers in microbiology 7: 2170.

Liu DW, Liu HB, Zhang HB, Cao MC, Sun Y and Lu CH (2016), Potential natural exposure of endangered red crowned crane (Grus Japonensis) to mycotoxins aflatoxin B1, deoxynivalenol, zearalenone, T-2 toxin, Ochratoxin A, Journal of Zhejiang University Science B 17(2): 158-68. DOI: 10.1631/jzus.B1500211

Nesbitt BF, O'kelly J, Sargeant K and Sheridan A (1962), Toxic metabolites of Aspergillus flavus, Nature, London 195(4846): 1062-1063.

Patterson DSP (1977), Aflatoxin and related compounds: Introduction In: Mycotoxic Fungi, Mycotoxins, Mycotoxicoses, an Encyclopaedic Handbook, pp 131-135.

Rosa CAR, Riberio JMM, Fraga MJ, Gatti M, Cavaglieri L R, Magnoli CE, Dalcero AM and Lopes CWG (2006), Mycoflora of poultry feed and ochratoxin producing ability of isolated Aspergillus and Penicillium species, Vetrinary Microbiology 113: 89-96. DOI: org/10. 1016/j.vetmic.2005.10.031 
Scudamore KA, Hetmanski MT, Nawaz S, Naylor J and Rainbird S (1997), Determination of mycotoxins in pet foods sold for domestic pets and wild birds using linked-column immunoassay clean-up and HPLC, Food Additives \& Contaminants 14(2): 175-186. DOI: org/10.1080/02652039709374512

Siame BA and Lovelace CE (1989), Natural occurrence of zearalenone and trichothecene toxins in maize-based animal feeds in Zambia, Journal of the Science of Food and Agriculture 49(1): 25-35. DOI: org/10. 1002/jsfa.2740490104

Smith JE and Moss MO (1985), Mycotoxin: Formation, analysis and significance, John Wiley and Sons, New York 148.
Ueno Y (1977), Trichothecenes: an overview address. Mycotoxins in human and animal health, pp 189-207.

Van der Zijden ASM, Koelensmid WAA, Boldixgh J, Barrett CB, Ord WO and Philp J (1962), Isolation in crystalline form of a toxin responsible for Turkey $\mathrm{X}$ disease, Nature, London, 195: 4846.

Yunus AW, Razzazi-Fazeli E and Bohm J (2011), Aflatoxin B1 in affecting broiler's performance, immunity and gastrointestinal tract: A review of history and contemporary issues, Toxins 3(6): 566-590. DOI: org $/ 10.3390 /$ toxins 3060566 